\title{
PUSAKA REMPAH DI NEGERI MARITIM
}

\author{
Anak Agung Ngurah Agung Wira Bima Wikrama \\ Fakultas Ilmu Sosial dan Ilmu Politik, Universitas Mahendradatta - Denpasar \\ e-mail:bimawikrama65.gmail.com
}

\begin{abstract}
Abstak - Pusaka Rempah di Negeri Maritim dapat dijadikan sebagai cermin bagi kita, karena alur cerita Negara Republik Indonesia dalam menghadapi tantangan kedepan yang sangat multi dimensional kelihatan meredup, sampai-sampai berbagai kalangan akhir-akhir ini sering kali berwacana "kembali ke UUD 45". Bahkan banyak diantaranya menggulirkan "NKRI Harga Mati". Sejauh ini apakah semua upaya telah dilakukan adalah merupakan tindakan produktif atau preventif dalam merajut untaian kebersamaan kembali sebagai sebuah Negara berdaulat, yang senantiasa gonjang-ganjing dalam suasana pertentangan dan penuh persaingan. Nampaknya bangsa serta negara ini belum mampu memanfaatkan khasanah budaya maupun iptek, kearifan lokal dan nasional untuk tampil kreatif dalam menyelesaikan persoalannya dan berani mengambil resiko terbesar serta merumuskan solusi unik enigmatik menjadi arus besar pelestarian sejarah budaya maritim. Diawali dari philosofi bahwa pantai-pantai kita saling berhadapan dan pulau-pulaunya adalah milik kita. Adapun keraton dan lembaga adat yang terdapat di dalamnya berjalan mengatur rakyatnya. Kedua ekspedisi Pamalayu, merupakan sebuah ekspedisi diplomasi ketenteraan yang dilakukan Kerajaan Singasari pada masa Raja Kertanagara pada tarikh 1275-1293 terhadap Kerajaan Melayu (atau dikenal juga sebagai Kerajaan Dharmasraya atau Kerajaan Jambi). Pada masa itu, Kerajaan Singasari menghendaki seluruh kawasan asia tenggara harus dikuwasai. Tentunya mereka sudah sangat memahami kemaritiman, alutsista dan dunia perkapalan. Ketiga Sriwijaya sebagai tonggak milenium pertama dalam kemaritiman dunia, mampu memindahkan perjalanan sutra yang awalnya lewat darat, kemudian dirubah melalui laut dan menggugurkan Perjanjian Tordesilas dibuat oleh Kepausan yang membagi laut menjadi dua kawasan yaitu kawasan barat dan timur. Sriwijaya dapat membuktikan dan menepis anggapan bahwa bagian laut setelah India ternyata tidak dikuasai oleh para hooligan, perompak, bajak laut dan sebagainya. Keempat Kerajaan Majapahit mampu menyatukan dan menata seluruh elemen-elemen kemaritiman nusantara yang dipimpin oleh panglima laut bernama Ranggalawe serta didukung konglomerat perkapalan nasional waktu itu bernama Nyai Kanggotan yang memiliki industri perkapalan berpusat di Tuban dengan kekuatan lebih dari 3200 jung jawa atau kapal jawa.
\end{abstract}

Kata Kunci: Pusaka, Rempah, Maritim

\begin{abstract}
Abstact - Spice inheritance in the oceanic country affairs can be used as a mirror for us, because the storyline of the Republic of Indonesia in facing future challenges wich is very multi-dimensional seems to fade away, there fore many groups lately often discuss back to the 1945 Constitution. In fact, many of them rolled out "NKRI Harga Mati". So far, all efforts have been made is a productive or preventive action in compousting together a string of reunion a sovereign country, which is always on the moves in an atmosphere of opposition and full of competitions. It seems that this nation and country have not been able to utilize the cultural and scientific treasures, local and national wisdom to appear creative in solving their problems and dare to take the greatest risks and formulate unique enigmatic solutions into a large current in preserving the history of maritime culture. Starting from the philosophy that our beaches face each other and the islands are ours. So that the palace and the traditional institutions contained inside running to regulate the people. Secondly Pamalayu Expedition is a military diplomatic expedition carried out by the Singasari Kingdom during The King Kertanagara's dated 1275-1293 against the Malay's Kingdom (also known as the Kingdom of Dharmasraya or the Kingdom of Jambi). At that time, the Singasari Kingdom wanted the entire Southeast Asian region to be ruled. Surely they already understood the maritime, defense equipments and the shipping knowledge.
\end{abstract}


The thirdly Srivijaya as the monumenthal of the first millennium in the maritime world, was able to remove the silk's journey which was originally by land, then changed by sea and cancelled the Tordesilas Agreement made by the Papacy which divided the sea into two regions namely the western and eastern regions. Srivijaya could prove and dismiss the notion that parts of the sea after India were apparently not ruled by hooligans, pirates, and etc. The fourthly Majapahit Kingdom was able to unite and organize all the maritime elements in the archipelago led by the sea commander in comand named Ranggalawe and supported by the national shipping conglomerate at the time named Nyai Kanggotan who had a shipping industry centered in Tuban with the strength of forces more than 3200 Java jung or Javanese tradicional ships.

Keywords: Heritage, Spice, Maritime

\section{Latar Belakang}

Berbicara Nasionalisme tidak dapat dilepaskan dari kata kemaritiman, karena dalam kenyataannya, negara ini terdiri dari pulau-pulau yang sebagian besar dan dihuni oleh kelompok masyarakat atau suku-suku berorientasi pada laut yang menjadi bagian kehidupannya. Itulah alasan dari YB. Mangunwijaya (almarhum) mengatakan bahwa NKRI adalah mitos abad 20. Beliau mengatakan bahwa kemajuan bangsa yang menempati kawasan Atlantis ini justru berjaya dan menguasai dunia kemaritiman secara internasional pada saat belum menjadi Negara Republik Indonesia. Ibarat sebuah dongeng, gagasan bangsa maritim sekarang masih menjadi hayalan "jati diri bangsa". Bukankah budaya maritim sudah ada dalam sanubarinya ?

Itulah gambaran tentang "postur budaya asli" masyarakat nusantara. Namun ketika menjadi Indonesia, prestasinya tidak menggelora seperti moyangnya. Prof. Umar Kayam menyitir orang Indonesia itu sebagai manusia bertulang animisme berbalut daging hindu, berjubah arab dan berparfum eropa, sekaligus sebagai tempat pembuangan sampah akhir peradapan dunia. Artinya Hindu, Budha, Islam maupun Kristen ketika disini telah bergeser jauh dari muasalnya. Dalam proses transmisi maupun komunikasi gagasan mengalami penurunan nilai sehingga perilaku peradabannya meluncur deras ke arah sebuah kepentingan kekuasaan. Selanjutnya terjadilah proses domistikasi budaya kolonilisasi maupun imperialisasi yang berlangsung sekian lama silih berganti serta mereposisi ke budaya darat. Hal tersebut semakin memperparah prespektif berbangsa dan bernegara serta nasional- isme yang ujung-ujungnya sangat rentan terhadap konflik.

Kejatuhan budaya maritim nusantara secara keseluruhan semenjak diberlakukannya perjanjian Bongaya antara Belanda dengan Sultan Hasannudin, praktis federasi kerajaan-kerajaan seluruh kawasan nusantara tersingkir ke wilayah tengah pulau sehingga kehilangan laut sebagai matra basis sumberdaya kehidupannya dan tidak berdaulat sama sekali terhadap lokal genius berupa pelaku pengembang iptek kemaritiman di wilayahnya sampai sekarang.

\section{Permasalahan}

Melihat betapa tangguhnya Sriwijaya, Singosari maupun Majapahit dipelataran kawasan Asia-Pasifik pada jamannya dengan memainkan peran besar mereka dalam dialektika geostrategi pada akhirnya menumbuhkan geopolitik, geoekonomi maupun geokultural dengan berfikir laut sebagai centrum penemuan jati diri sesuai takdir alamiahnya.

Presiden pertama Republik Indonesia Bung Karno terlambat menyadari dan buru-buru disusul Presiden Gus Dur membentuk Departemen Eksplorasi Laut kemudian sekarang menjadi Kementerian Kemaritiman. Mengukur budaya maritim tidak hanya bertumpu pada soal bagaimana mengeksplorasi dan mengeksploitasi laut sebagai sumberdaya. Laut adalah matra lintas sektor berkait dengan berbagai aspek kompetensi budaya kreatif dengan memaknai kemajuan bangsa dalam menjalankan transaksi-transaksi ekonomi, sosial, politik, budaya, pertahanan dan keamanan. Hukum dalam bingkai keselarasan dan kebersamaan secara universal dengan 
bangsa-bangsa lain di dunia.

Sayangnya pada saat kemerdekaan 17 Agustus 1945, infrastruktur kemaritiman nasional tidak pernah dibangun kembali oleh Negara Republik Indonesia. Bahkan kapal-kapal pampasan perang dulu milik Belanda ikut ditarik oleh Negara sekutu. Mereka hanya meninggalkan alutsista artleri darat saja, Ternyata dikemudian hari hal ini sangat berpengaruh terhadap pembangunan pertahanan kewilayahan yang ikut-ikutan berbasis darat. Pada akhirnya merasuk pada sistem penganggaran nasional. Lihat saja dalam pengembangan wilayah kelautan yang sangat minim anggaran dibanding daratan. Dapat dilihat bahwa pemerintah gagal membangun laut sebagai wilayah pertahanan maupun kedaulatan nasional. Padahal kita punya Zona Ekonomi Eksklusif (ZEE) dan pulaunya saling berhadapan. Negara Indonesia dapat diandaikan sebagai wilayah yang dibungkus oleh laut, yang didalamnya terdiri dari berupa pulau-pulau. Jadi bangsa ini sesungguhnya tidak pernah berfikir ke"benua"an, seperti disebut dalam deklarasi Juanda 1957 yang menegaskan : pertama, bahwa Indonesia menyatakan sebagai Negara kepulauan yang mempunyai corak tersendiri, kedua dari dulu nusantara merupakan satu kawasan, jadi ketika antar pulau dihubungkan dengan jembatan akibatnya membunuh hampir seluruh armada Angkutan Sungai dan Pesisir, beribu masyarakat pekerja sektor laut menjadi pengangguran, mari bandingkan dengan Negara Thailand demikian ngotot ingin membuka "Terusan Kra atau Kra Gate" membelah daratan Thailand jadi dua dipropinsi Pattani. Dampak berikutnya adalah, Thailand secara pasti mengganti kedudukan Singapura sebagai pelabuhan distribusi dunia dan kawasan Asia-Pasifik.

Bagaimana dengan Indonanesia ? Pertanyaan yang harus dijawab oleh bangsa Indonesia sendiri. Seperti yang diangankan oleh Bung Karno bahwa : pertama pelabuhan Sabang dapat hidup sebagai pelabuhan penghubung Sabang-Belawan-Pattani (Triangle Port), kedua kekuatan ekonomi maritim internasional berpaling ke Indonesia. Banyak bacaan bisa dijelaskan dari persoalan di atas, betapa perkembangan dunia kemaritiman sangat dinamis. Sekarang perlu menata ulang diantaranya pulau-pulau terdepan nusantara banyak dikuasasi orang asing, pencurian ikan, perampokan, penyelundupan kayu, minyak, manusia, tempat pembuangan sampah di laut, penambangan liar pasir laut, bahkan apabila terjadi kecelakaan di laut, kapasitas Search and Rescue laut kita boleh dikatakan sangat terbatas, sehingga penanganan keselamatan di seluruh perairan nusantara termasuk paling buruk didunia.

Sebaiknya sekarang pemerintah harus terjun ke laut untuk semua sektor, tidak seperti dulu lagi hanya hadir di pulau-pulau besar wilayah nusantara saja, sementara di laut dan pulau-pulau kecil tidak menampakkan diri secara efektif. Padahal pola pikir pesisir dan maritim adalah pola berfikir dinamis, demokratis dan egaliter. Gelombang laut adalah gelombang impian kemajuan dan arus laut adalah arus kemauan terus maju pantang mundur. Lihatlah karakter orang-orang laut punya kemauan keras, impian tinggi dan mampu mewujudkan walau badai menerjang, mereka terus melaju bersama ujung-ujung bercadik melibas gelombang, namun sayang seiring perkembangan Indonesia saat ini, marwah kemaritiman tersebut terzolimi oleh bangsa barat yang hanya disebabkan oleh pertengkaran dengan keluwarga sendiri tak kunjung selesai. Lebih suka berbicara lewat ujung keris dan tombak, sehingga kehilangan rumusan kreatifitas kebudayaan dan kehilangan jati dirinya sebagai insan maritime. Pada akhirnya kembali menjadi bangsa inlander.

\section{Tantangan}

Dalam pidato pengukuhan Ernest Renant sebagai guru besar di universitas Sorbonne mengatakan, apakah bangsa itu...? Beliau mengatakan bahwa "Bangsa adalah suatu kaum yang sama-sama didera oleh penderitaan, tanpa mengenal ras, agama, kebudayaan dan sama-sama punya jiwa untuk terlepas dari itu" definisi di atas sangat cocok dengan kondisi Indosesia saat ini yang sejak 1835 terus dihempas oleh kolonialisme dan imperialisme mulai dari Portugis, Inggris, Belanda maupun Jepang. Dengan sekehendak hati para penjajah menguras kekayaan negri ini yang terdiri dari 17.000 pulau besar kecil serta memporakporandakan semua lini kehidupan bangsa berbudaya maritime. Bukan tidak ada perlawanan namun dengan mudah para penjajah mematahkannya karena 
perlawanan masih bersifat lokal dan tidak semua warga mendukungnya. Setelah kemerdekaan tercapai, berikutnya terjadi malapetaka akademik berjalan sampai hari ini dan dampaknya melebihi dari masa penjajahan.

Bagaimana mungkin semua proses kependidikan di negri ini hasilnya adalah mencetak pribadi tanpa mengenal sejarah maupun letak wilayah geografis negrinya. Ketika ditanya disebelah mana posisi lautan hindia, morotai, teluk tomini di dalam peta Indonesia. Kemudian hasil-hasil dari satu wilayah berupa komoditi. Dari sekian banyak para peseta didik tidak ada satupun menjawab dengan benar pertanyaan tersebut. Apakah mereka tidak merasa sesak nafas hidup dalam wawasan sempit, bahwa Indonesia digambarkan hanya seluas Pulau Bali sampai Jakarta. Padahal yang namanya nusantara tak bakal habis kalau hanya dibicarakan saja. Sepertinya mereka tidak perlu mengenal Indonesia beserta penghuninya apalagi sejarahnya yang terbentang luas dari Sabang sampai Merauke dari Miangas sampai Pulau Rote. Ini sebuah tragedi pelumpuhan total terhadap eksistensi nilai-nilai kebangsaan dalam mengemajinasikan teritorial nusantara dengan menggambarkan Indonesia secara utuh. Maka terhadap seluruh elemen masyarakat khususnya generasi muda dan bagi penguasa atau pejabat Negara bersama-sama belajar menemukan dan mengenali kembali bentangan kenusantaraan berikut menyangkut segala isi perut bumi maupun lautnya.

Sebagai tantangan berikutnya adalah bagaimana membangkitkan kembali kesadaran budaya kemaritiman serta bertekad bulat menolak subordinasi ke"benua"an yang ditanamkan dalam proses pembelajaran kepada peserta didik dari tingkat Sekolah Dasar sampai Perguruan Tinggi yang telah ditanamkan oleh para penjajah melalui sistem pendidikan nasional kita. Seperti di atas telah disebutkan bahwa jati diri bangsa sebagian besar dapat ditelusuri melalui sejarah pendidikannya, dimana pendidikan modern kita didominasi dan didesain untuk kepentingan penjajah. Sudah kita lihat hasilnya yaitu kita tetap berpikir daratan. Kajian-kajian kemaritiman sengaja tidak dikembangkan yang akibatnya adalah pembangunan kemaritiman terbelakang. Padahal prospek dunia kemar- itiman membentang mulai dari industri pelayaran, industri galangan kapal, pabrikasi bangunan laut, perikanan tangkap, marinekultur dan offshore fish farming, bioteknologi termasuk di dalamnya indistri farmasi, kosmetika dan makanan laut, industri garam, penambangan mineral, industri energi laut, wisata bahari dan masih banyak lagi dan yang jelas dengan luas laut Indonesia sangat besar, ternyata masih kalah sumbangan sektor kelautan dalam PDRB nasional dibandingkan dengan Negara bukan maritim seperti China maupun Thailand. PDRB kita masih $27 \%$ jauh dibawah mereka.

Barangkali globalisasi berserta gagasan-gagasannya telah melabrak habis bangsa ini hingga bangsa ini menjadi bebek-bebek pengekor tuannya. Sangat sulit bangsa ini membangun kembali keseimbangan saat bangsa ini membutuhkan pembentukan nalar jati diri. Globalisasi adalah Amerikanisasi (H.Kessinger 1988) dan dengan sengaja memandegkan nilainilai kearifan Indonesia. Semua diarahkan ke sebuah "satuisme" seperti halnya pasar global, ekonomi global, ideology global. Selanjutnya bangsa ini tidak memiliki harkat, martabat dan tampak ela-elo atau eleg-eleg. Mudah terombang-ambing dan tanpa sadar hidupnya sebagai orang yang bebas secara pluralistik.

\section{Penutup}

Sesungguhnya budaya maritim sangat melekat pada diri bangsa nusantara. Bangsa ini telah melahirkan tokoh kemartiman kelas dunia dan sangat diperhitungkan di kawasan Asia-Pasifik tempo dulu. Orang tersebut bernama Jalamangkara berasal dari Tuban. Beliau adalah ahli pembuat kapal niaga ukuran sangat besar dan terkenal dengan nama "Jung Jawa". Sejarah telah mencatat bahwa Jalangmangkara diutus ke Bugis untuk mendisain ulang kapal phinisi supaya dapat memuat barang dagangan lebih banyak. Selanjutnya diutus pula beliau ke negeri China untuk penelitian yang sama pada jaman dinasti Ming. Jadi secara eksplisit senyatanya bangsa ini mampu menunjukan aspek-aspek intelektualitas dan keahliannya pada tataran kelas dunia dalam kemaritiman sekaligus menjadi doktrin ideologis membangun kesadaran nasionalisme tanpa mengabaikan tanggung jawab kawasan dan sekali- 
gus sebagai sarana diplomasi antara berbagai negara besar di kawasan Asia-Pasifik khususnya negri China. Dikemudian hari kapal-kapal niaga China hampir semuanya berubah menjadi besar dalam ukuran tonase, namun tidak pernah muncul konflik kepentingan antar Negara.

Kita telah disadarkan kembali bahwa bangsa ini mempunyai "roh kolektif kemaritiman" dan mampu merumuskan tafsir yang bukan sebagai pemahaman "ke-benua-an". Dalam prespektif untuk menentukan titik tolak pelurusan jejak sejarah maritime tidaklah mudah. Diperlukan waktu yang panjang. Karena hampir semua kerajaan dan suku-suku pesisir diseluruh nusantara sebagai federasi steakholder kebudayaan maritim nusantara dan menetapkan laut adalah wilayah kedaulatannya, saat ini sudah berubah orientasi. Orientasi maritime negeri ini sudah porak-poranda oleh orientasi benoa atau daratan. Harapan kedepan adalah jangan sampai negeri ini dijajah kembali hingga tiga abad lamanya dengan menerapkan politik pecah belah dan penguasaan wilayah perairan. Artinya mereka menguasai nusantara dengan menghancurkan kemampuan kemaritiman negeri ini, kemudian menguasai perdagangan antar pulau-pulau di nusantara.

\section{Daftar Pustaka}

Direktorat Sejarah, Direktorat Jenderal Kebudayaan, Kementerian Pendidikan dan Kebudayaan, 2017, Jalur rempah: dan dinamika masyarakatnya abad X-XVI : Kepulauan Banda, Jambi, dan Pantai Utara Jawa

Marihandono, Djoko, 2016, Rempah, jalur rempah, dan dinamika masyarakat Nusantara, Direktorat Sejarah, Direktorat Jenderal Kebudayaan, Kementerian Pendidikan dan Kebudayaan.

Vlekke, Bernard H.M., 2008, Nusantara: sejarah Indonesia, Gramedia Jakarta.

Ricklefs, M.C., 2001, Sejarah Indonesia modern, 1200-2004, Palgrave.

Waridi,St.S., 2018, Nasionalisme Indonesia Tanpa Kemaritiman.....?, Dewan Adat dan Tradisi Budaya Nusantara. 